\title{
Beare-Stevenson cutis gyrata syndrome: A new case of a c.1124C $\rightarrow$ G (Y375C) mutation in the FGFR2 gene
}

\author{
RENATA FRAGELLI FONSECA ${ }^{1}$, MARCELO AGUIAR COSTA-LIMA ${ }^{1,2}$, ELIANA TERNES PEREIRA ${ }^{3}$, \\ EDUARDO ENRIQUE CASTILLA ${ }^{4}$ and IÊDA MARIA ORIOLI ${ }^{1}$ \\ ${ }^{1}$ ECLAMC (Estudo Colaborativo Latino Americano de Malformações Congênitas) at Departamento de Genética, \\ Universidade Federal do Rio de Janeiro, Avenida Brigadeiro Trompowski s/n, Cidade Universitária, Rio de Janeiro, \\ CEP 21944-970; ${ }^{2}$ Departamento de Biologia Celular e Genética, Universidade do Estado do Rio de Janeiro, \\ Rua São Francisco Xavier 524, Maracanã, Rio de Janeiro, CEP 20550-013; ${ }^{3}$ Departamento de Clínica Médica, \\ Universidade Federal de Santa Catarina, Campus Universitário, Florianópolis, Santa Catarina, \\ CEP 88040-900; ${ }^{4}$ ECLAMC at Departamento de Genética, Instituto Oswaldo Cruz, FIOCRUZ, \\ Av. Brasil 4365, Manguinhos, Rio de Janeiro, CEP 21045-900, Brazil
}

Received April 17,2008; Accepted June 13, 2008

DOI: $10.3892 / \mathrm{mmr}+00000024$

\begin{abstract}
Beare-Stevenson syndrome (BSS) (MIM\#123790) is a rare disorder characterized by craniofacial anomalies and cutis gyrata associated with anogenital anomalies and prominent umbilical stump. There are few reports on the syndrome, and molecular analysis has revealed the involvement of two closely spaced mutations within the FGFR2 gene: c.1115C $\rightarrow \mathrm{G}$ (p.S372C) and c.1124C $\rightarrow \mathrm{G}$ (p.Y375C). We herein describe a new case of a c. $1124 \mathrm{C} \rightarrow \mathrm{G}$ mutation in a BSS patient.
\end{abstract}

\section{Introduction}

Beare-Stevenson syndrome (BSS) is a rare disorder characterized by a series of symptoms, recognizable at birth, which include cutis gyrata, craniosynostosis, acanthosis nigricans and craniofacial, umbilical and anogenital anomalies (1-5). These symptoms overlap with other disorders, such as Crouzon syndrome; however, the prognosis for BSS is worse than in these other disorders (6). BSS cases are sporadic, and a paternal age effect has been suggested $(4,7,8)$. Molecular analysis of BSS cases has revealed two closely spaced mutations in exon 11 of the FGFR2 gene: c. $1115 \mathrm{C} \rightarrow \mathrm{G}(\mathrm{S} 372 \mathrm{C})$ in 2 patients and c. $1124 \mathrm{C} \rightarrow \mathrm{G}(\mathrm{Y} 375 \mathrm{C})$ in 9 patients $(4,6,8-14)$.

Fibroblast growth factor receptors (FGFRs) comprise a family of tyrosine kinase receptors. Four of their members have been identified in humans, and three of these are associated with developmental disorders. Heterozygous mutations in

Correspondence to: Dr Iêda Maria Orioli, Departamento de Genética, Universidade Federal do Rio de Janeiro, Caixa Postal 68.011, Rio de Janeiro, CEP 21944-970, Brazil

E-mail: orioli@centroin.com.br

Key words: FGFR2 gene, Beare-Stevenson cutis gyrata syndrome
FGFR1-3 genes have been identified in several syndromic craniosynostoses, including the Apert, Crouzon, Pfeiffer, Jackson-Weiss, BSS, Antley-Bixler, Muenke and Crouzonodermoskeletal syndromes, and at least 40 allelic variants of FGFR2 have been described to date (Table I) (15-17). Other genes have also been implicated in syndromic craniosynostosis, including MSX2 in Boston type craniosynostosis (18), TWIST in Saethre-Chotzen syndrome (19), POR in Antley-Bixler syndrome (20) and NFBI in craniofrontonasal syndrome $(21,22)$.

In the present study, we describe a new case of a c. $1124 \mathrm{C} \rightarrow \mathrm{G}(\mathrm{Y} 375 \mathrm{C})$ mutation in a BSS patient.

\section{Case report}

The patient was the product of a 41 -week gestation to a G2P2Ab0 23-year-old mother and a 30-year-old unrelated father. Delivery was by cesarian section. At birth, the head circumference was $35 \mathrm{~cm}$, birth weight was $3,985 \mathrm{~g}$ and birth length was $50.5 \mathrm{~cm}$. Clinical examination showed several anomalies, among them a cloverleaf skull, high forehead, lowset ears, corrugated skin overlying the scalp, face, ears, palms, soles and labia majora, mild face hypoplasia, choanal atresia, neonatal teeth, corrugated high palate, globulous abdomen, prominent umbilical stump, perineal fissure from genital to anal mucosa and lumbosacral dimple.

Chromosomal analysis by GTG banding revealed a normal 46,XX karyotype. Blood samples were obtained from the patient and her mother. The child died on day 1 , and a postmortem examination was refused.

\section{Results}

After informed consent was obtained, molecular screening was performed by PCR-direct sequencing. DNA was extracted according to standard procedures (23), and $100 \mathrm{ng}$ was used to amplify a segment containing exon 11 of FGFR2. PCR was conducted in an MJ PTC200 thermocycler (Waltham, MA, 
Table I. Involvement of the FGFR gene family members in syndromic craniosynostosis with known mutations ${ }^{\text {a }}$

\begin{tabular}{|c|c|c|c|c|c|}
\hline Gene & MIM & $\begin{array}{l}\text { Chromosomal } \\
\text { location }\end{array}$ & Syndrome & OMIM & Mutations $^{\mathrm{b}}$ \\
\hline \multirow[t]{2}{*}{ FGFR1 } & 136350 & 8p11.2-p11.1 & Pfeiffer & 101600 & P252R \\
\hline & & & Crouzon & 123500 & $\begin{array}{l}\text { Y105C, S252L }{ }^{c}, \text { P253L, H254Y, P263L, S267P, } \\
\text { F276V, C278F, C278Yc, Y281C, I288S, Q289P, } \\
\text { W290R, W290C, W290G, L292E, Y308C, D321A } \\
\text { Y328C, A337P, G338R, Y340S, Y340H, C341P, } \\
\text { C342F, C342Y, C342R, C342S, C342W, A344A, } \\
\text { S347C, S354C, S354F, A326Sc , K526Ec , N549H }\end{array}$ \\
\hline \multirow[t]{5}{*}{$F G F R 2$} & 176943 & $10 q 26$ & Pfeiffer & 101600 & $\begin{array}{l}\text { A172F, S252L, P253S, S267P, C278F, W290C, } \\
\text { Y340C, T341P, C342R, C342S, C342Y, S351C, } \\
\text { S352P, Y375C, N549T, E565A, E565G, K641R, } \\
\text { G663E }\end{array}$ \\
\hline & & & Apert & 101200 & S252W, S252F, P253R \\
\hline & & & Beare-Stevenson & 123790 & S372C, Y375C \\
\hline & & & Jackson-Weiss & 123150 & C342R, C342S, A344G \\
\hline & & & Antley-Bixler & 207410 & C342R, C342S, S351C \\
\hline \multirow[t]{2}{*}{ FGFR3 } & 134934 & $4 \mathrm{p} 16.3$ & Muenke & 602849 & $\mathrm{P} 250 \mathrm{R}^{\mathrm{c}}$ \\
\hline & & & $\begin{array}{l}\text { Crouzon with } \\
\text { acanthosis nigricans }\end{array}$ & 123500 & A391E \\
\hline$F G F R 4$ & 134935 & 5q35.1-qter & ND & - & - \\
\hline
\end{tabular}

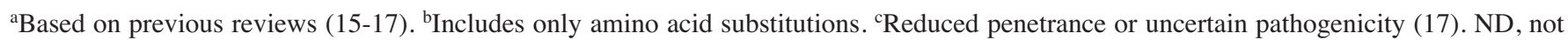
determined.

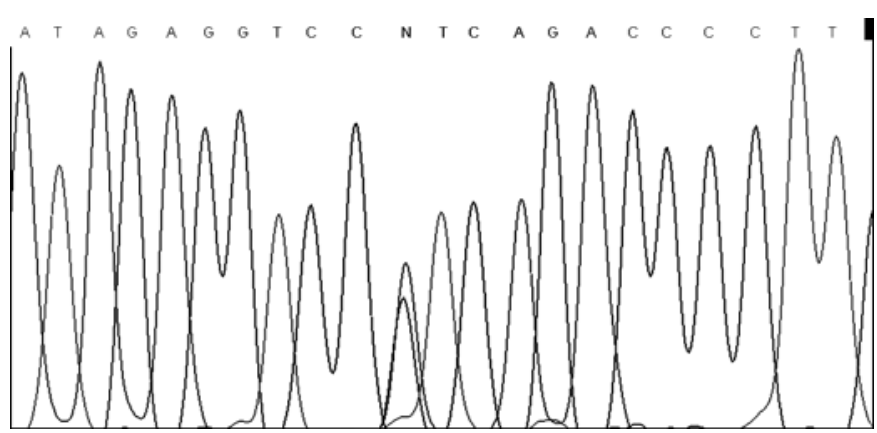

Figure 1. Chromatogram showing the presence of a transition $(c .1124 \mathrm{~A} \rightarrow \mathrm{G})$ in the proposita.

USA) using the Enhancer Kit (Invitrogen, Carlsbad, CA, USA) with cycling conditions and primers as described elsewhere (12). Sequencing was performed using Dyenamic ${ }^{\mathrm{TM}}$ ET Dye Terminator Kit Megabace ${ }^{\mathrm{TM}}$ (GE Healthcare Biosciences, Buckinghamshire, UK) according to the manufacturer's instructions in a Megabace 1000 ${ }^{\mathrm{TM}}$ (GE Healthcare Biosciences), and revealed a heterozygous transition at nucleotide 1124 $($ c.1124A $\rightarrow \mathrm{G})($ Fig. 1) that promotes the substitution of a tyrosine by a cysteine residue (p.Y375C). This mutation was not found in the mother.

\section{Discussion}

To date, FGFR2 mutations have been reported in 11 BSS patients. Two cases harbored a c. $1115 \mathrm{C} \rightarrow \mathrm{G}$ transversion $(9,14)$ located in the carboxyl-terminal end of the linker region between the immunoglobulin III-like (Igll1) and transmembrane domains of the protein, and 9 cases harbored a c. $1124 \mathrm{~A} \rightarrow \mathrm{G}$ transition $(4,8-13)$ located in the transmembrane region of the protein. In 2 patients, no FGFR2 mutations were detected, suggesting further genetic heterogeneity (9). One unique report revealed a chromosomal abnormality with a 46XY,t(7;18)(q35;q21) karyotype (24); however, no molecular analysis was performed in this case.

While the Crouzon and Pffeifer syndromes can be caused by an impressive number of different FGFR2 mutations, the Apert, Beare-Stevenson, Jackson-Weiss and Antley-Bixler syndromes are caused by a restricted number of FGFR2 mutations. The same mutation can, however, occur in different syndromes. For example, p.C342R has been described in the Crouzon, Pfeiffer, Jackson-Weiss and Antley-Bixler syndromes. The p.Y375C substitution in the FGFR2 gene has also been described in a patient with severe Pfeiffer syndrome presenting a cloverleaf skull, prominent labia majora and sacral appendage, but without cutis gyrata (26). On the other hand, a mutation in the FGFR3 gene (p.P250R) was described 
in a man and his daughter affected with atypical BSS-like features (25).

The phenotypic spectrum of BSS is wide; however, to date all patients harboring FGFR2 mutations have been reported to present preauricular creases, umbilical stump, abnormal cranial shape, craniosynostosis, midface hypoplasia, and proptosis. Our patient presented neonatal teeth, a feature that has only been previously described once (1).

Our case confirms the high morbidity and fatal outcome generally associated with BSS, irrespective of the FGFR2 mutation involved. The oldest patient reported reached 13 years of age (1), while over $60 \%$ of the patients with FGFR2 mutations die before 2 years of age. The mean paternal age reported in the literature seems to be high $(38.7 \pm 11.5$, range $24-62$, in accordance with the notion that FGFR2 mutations arise from the male chromosome (5). However, no paternal age effect can be assumed in the present case, and further analysis of additional patients is necessary for an association to be established.

\section{Acknowledgements}

We are grateful to Dr Hector Seuanez at the Genetics Division of INCa (Instituto Nacional de Câncer) for use of the sequencing facilities, and to Maura S. Silva for technical assistance. This study was supported by a grant from CNPq (308885/ 2006-6) and from FAPERJ (E-26-152.831/2006).

\section{References}

1. Beare JM, Dodge JA and Nevin NC: Cutis gyratum, acanthosis nigricans and other congenital anomalies. A new syndrome. Br J Dermatol 81: 241-247, 1969.

2. Stevenson RE, Ferlauto GJ and Taylor HA: Cutis gyratum and acanthosis nigricans associated with other anomalies: a distinctive syndrome. J Pediatr 92: 950-952, 1978.

3. Cohen MM Jr: Craniosynostosis update 1987. Am J Med Genet 4: 99-148, 1988

4. Hall BD, Cadle RG, Golabi M, Morris CA and Cohen MM Jr: Beare-Stevenson cutis gyrata syndrome. Am J Med Genet 44: 82-89, 1992.

5. Moloney DM, Slaney SF, Oldridge M, Wall SA, Sahlin P, Stenman G and Wilkie AO: Exclusive paternal origin of new mutations in Apert syndrome. Nat Genet 13: 48-53, 1996.

6. Akai T, Iizuka H, Kishibe M, Kawakami S, Kobayashi A and Ozawa T: A case of Beare-Stevenson cutis gyrata syndrome confirmed by mutation analysis of the fibroblast growth factor receptor 2 gene. Pediatr Neurosurg 37: 97-99, 2002.

7. Hehr U and Muenke M: Craniosynostosis syndromes: from genes to premature fusion of skull bones. Mol Genet Metab 68: 139-151, 1999.

8. McGaughran J, Sinnott S, Susman R, Buckley MF, Elakis G, Cox T and Roscioli T: A case of Beare-Stevenson syndrome with a broad spectrum of features and a review of the FGFR2 Y375C mutation phenotype. Clin Dysmorphol 15: 89-93, 2006.

9. Przylepa KA, Paznekas W, Zhang M, Golabi M, Bias W, Bamshad MJ, Carey JC, Hall BD, Stevenson R, Orlow S, Cohen MM Jr and Jabs EW: Fibroblast growth factor receptor 2 mutations in Beare-Stevenson cutis gyrata syndrome. Nat Genet 13: 492-494, 1996.
10. Krepelova A, Baxova A, Calda P, Plavka R and Kapras J: FGFR2 gene mutation (Tyr375Cys) in a new case of Beare-Stevenson syndrome. Am J Med Genet 76: 362-364, 1998.

11. Wang TJ, Huang CB, Tsai FJ, Wu JY, Lai RB and Hsiao M: Mutation in the FGFR2 gene in a Taiwanese patient with BeareStevenson cutis gyrata syndrome. Clin Genet 61: 218-221, 2002.

12. Pardo-Vargas RA, Maegawa GH, Taucher SC, Leite JC, Sanz P, Cifuentes J, Parra M, Munoz H, Maranduba CM and PassosBueno MR: Beare-Stevenson syndrome: Two South American patients with FGFR2 analysis. Am J Med Genet A 121: 41-46, 2003.

13. Eun SH, Ha KS, Je BK, Lee ES, Choi BM, Lee JH, Eun BL and Yoo KH: The first Korean case of Beare-Stevenson syndrome with a Tyr375Cys mutation in the fibroblast growth factor receptor 2 gene. J Korean Med Sci 22: 352-356, 2007.

14. Fonseca RF, Costa Lima MA, Cosentino V and Orioli IM: Second case of Beare-Stevenson syndrome with an FGFR2 Ser372Cys mutation. Am J Med Genet A 146: 658-660, 2008.

15. Passos-Bueno MR, Wilcox WR, Jabs EW, Sertie AL, Alonso LG and Kitoh $\mathrm{H}$ : Clinical spectrum of fibroblast growth factor receptor mutations. Hum Mutat 14: 115-125, 1999.

16. Muenke M and Wilkie AO: Craniosynostosis syndromes. McGraw-Hill, New York, 2000.

17. Wilkie AO, Bochukova EG, Hansen RM, Taylor IB, RannanEliya SV, Byren JC, Wall SA, Ramos L, Venancio M, Hurst JA, O'Rourke AW, Williams LJ, Seller A and Lester T: Clinical dividends from the molecular genetic diagnosis of craniosynostosis. Am J Med Genet A 140: 2631-2639, 2006.

18. Ma L, Golden S, Wu L and Maxson R: The molecular basis of Boston-type craniosynostosis: the Pro148His mutation in the Nterminal arm of the $M S X 2$ homeodomain stabilizes DNA binding without altering nucleotide sequence preferences. Hum Mol Genet 5: 1915-1920, 1996.

19. El Ghouzzi V, Le Merrer M, Perrin-Schmitt F, Lajeunie E, Benit P, Renier D, Bourgeois P, Bolcato-Bellemin AL, Munnich A and Bonaventure J: Mutations of the TWIST gene in the SaethreChotzen syndrome. Nat Genet 15: 42-46, 1997.

20. Fluck CE, Tajima T, Pandey AV, Arlt W, Okuhara K, Verge CF, Jabs EW, Mendonça BB, Fujieda K and Miller WL: Mutant P450 oxidoreductase causes disordered steroidogenesis with and without Antley-Bixler syndrome. Nat Genet 36: 228-230, 2004.

21. Twigg SR, Kan R, Babbs C, Bochukova EG, Robertson SP, Wall SA, Morriss-Kay GM and Wilkie AO: Mutations of ephrin-B1 (EFNB1), a marker of tissue boundary formation, cause craniofrontonasal syndrome. Proc Natl Acad Sci USA 101: 8652-8657, 2004.

22. Wieland I, Jakubiczka S, Muschke P, Cohen M, Thiele H, Gerlach KL, Adams RH and Wieacker P: Mutations of the ephrin-B1 gene cause craniofrontonasal syndrome. Am J Hum Genet 74: 1209-1215, 2004.

23. Miller SA, Dykes DD and Polesky HF: A simple salting out procedure for extracting DNA from human nucleated cells. Nucleic Acids Res 16: 1215, 1988.

24. Andrews JM, Martins DMFS, Ramos RR and Ferreira LM: A severe case of Beare-Stevenson syndrome and associated congenital deformities. Br J Plast Surg 46: 443-446, 1993.

25. Roscoli T, Flanagan S, Mortimore RJ, Kumar P, Weedon D, Masel J, Lewandowski R, Hyland V and Glass IA: Premature calvarial synostosis and epidermal hyperplasia (Beare-Stevenson syndrome-like anomalies) resulting from a P250R missense mutation in the gene encoding fibroblast growth factor receptor 3 . Am J Med Genet 101: 187-194, 2001.

26. Kan S, Elanko N, Johnson D, Cornejo-Roldan L, Cook J, Reich EW, Tomkins S, Verloes A, Twigg SRF, Rannan-Eliya S, McDonald-McGinn DM, Zackai EH, Wall SA, Muenke M and Wilkie AOM: Genomic screening of fibroblast growth-factor receptor 2 reveals a wide spectrum of mutations in patients with syndromic craniosynostosis. Am J Hum Genet 70: 472-486, 2002 . 